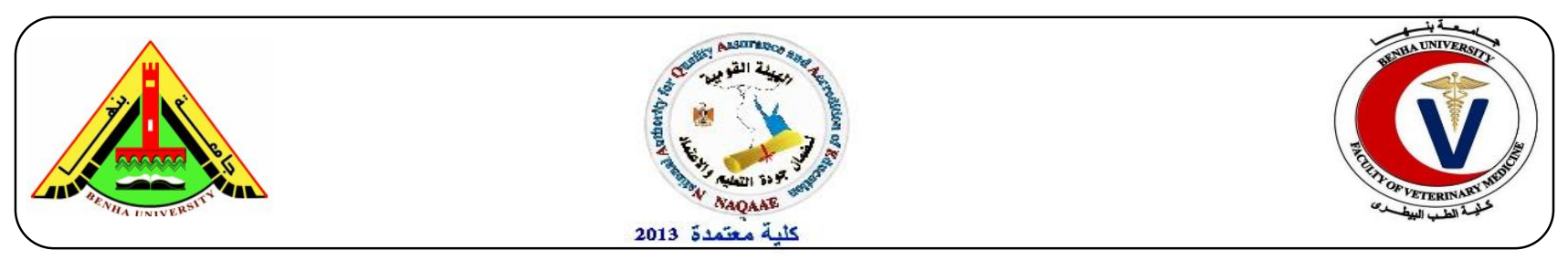

\title{
Comparison of SYBR Green real time PCR assay and conventional PCR for identity some commercial live poultry veterinary vaccines
}

\author{
Hala Mahmoud, Ahmed Maher, Reem Soliman, Marwa Fathy, Mounir M Elsafty, Mohamed \\ AbdelKhalek
}

Central Laboratory for Evaluation of Veterinary Biologics

\begin{abstract}
A B S T R A C T
Escherichia coli (E.coli) continue to be one of the major causes of food poisoning in the world. Different methods have been developed in order to reduce the time for the evaluation of the E.coli vaccines. Infectious bronchitis (IB) is a highly contagious viral disease of poultry causes economic losses. Control of IB virus has been attempted using live attenuated and inactivated vaccines. Due to the continuous emergence of E.coli and infections bronchitis, it was important to find a rapid accurate method of evaluation of the used live attenuated E.coli and IB vaccines. In this study, three assays, namely a conventional identification methods including; Specific Pathogen Free eggs (SPF) eggs inoculation for IB vaccine and culture method for E.coli vaccine, conventional polymerase chain reaction (PCR) assay and SYBR Green I Real-Time PCR method were developed and evaluated on 10 fold serial dilutions of each vaccine. A comparative analysis of these three assays was then performed, and the results indicated that the SYBR Green I Real-Time PCR had the highest sensitivity and specificity.
\end{abstract}

Keywords: E. coli, IB vaccines, PCR.

(http://www.bvmj.bu.edu.eg) $\quad$ (BVMJ-35(2): 57-66, 2018)

\section{INTRODUCTION}

E. coli is a major cause of food poisoning in the world. Different techniques have been developed in order to reduce the time for the evaluation of the E.coli vaccines, since the International Organization for Standardization (ISO) standard cultural method requires up of five days. Many of the PCR assays employ either visual scoring of ethidium bromidestained agarose gels or post-PCR hybridization-capture methods that are labour intensive, time consuming and difficult to automate. To date, the use of SYBR Green I for the identification of PCR product allows an early and simple approach to the Real-Time PCR and require less knowledge than classic Real-time PCR using fluorogenic oligoprobes (Hoorfar et al., 2000).

Infectious bronchitis (IB) is a highly contagious viral disease of poultry caused by infectious bronchitis virus (IB), a member of the genus Gamma corona virus, family Coronaviridae, and order Nidovirales. This disease is characterized by respiratory signs and nephritis, leading to the yield of both meattype and egg-laying birds being affected (ICTV virus taxonomy 2009). Thus, IB causes 
considerable economic losses within the poultry industry, and therefore, IB virus is considered as a major pathogen in poultry production (OIE 2018.). The IB virus genome consists of a single-stranded positive-sense RNA molecule of approximately $27.6 \mathrm{~kb}$ that encodes several nonstructural proteins involved in RNA transcription and replication and four structural proteins: small membrane $(\mathrm{E})$, membrane $(\mathrm{M})$, nucleoprotein $(\mathrm{N})$ and spike (S), which is formed by a globular S1 subunit that is anchored in the membrane by the S2 subunit (Cavanagh 2007).

Since IB virus was first described by Schalk and Hawn in the 1930s (Schalk and Hawn 1931), many serotypes have been identified worldwide. Control of IB virus has been attempted using live attenuated and inactivated vaccines. Due to the continuous emergence of new variants of the IB virus, the identification of the type of IB virus causing an outbreak in commercial poultry is important in the selection of the appropriate vaccine(s) capable of inducing a protective immune response (Ana et al., 2013).from this point it was important to find a rapid accurate method of evaluation of the used live attenuated IB vaccines.

The fluorescent-probe-based assays require availability of primers and probes that must be selected according to very rigid conditions, which cannot always be easily applied. Use of the double stranded DNA (dsDNA) binding dye SYBR Green I for identification of PCR products has overcome this limitation by allowing real-time PCR to be applied without the need for probes linked to fluorescent molecules Protocols that are already in use for classic PCR can thus be used with only slight modifications. In the absence of probes, specificity of the reaction is determined by melting temperature (Tm) of the amplicon obtained, defined as the temperature at which $50 \%$ of the DNA amplicon is in a double stranded configuration (Hyang-Mi et al.,
2005). Recently, more researchers rely upon real-time PCR studies using simple and less expensive SYBR Green dye. A number of SYBR Green real-time PCR assays for identification of microbial pathogens such as Escherichia coli O157:H7 have been reported. (Jothikumar and Griffiths, 2002)

The objective of the present study was to develop and evaluate a SYBR Green I RealTime PCR method for the specific identification and identification of live attenuated vaccines that would be suitable for routine analysis of these vaccines samples.

To confirm the effectiveness of the proposed method experiments were conducted with two different live vaccines. The current study was undertaken to develop a simple, inexpensive, sensitive and specific SYBR Green I quantitative real-time PCR method for separate identification of E.coli and IB in live attenuated vaccines.

In this study, three assays, namely a conventional identification methods (cultural method for E.coli and SPF inoculation for IB virus), conventional PCR assay and SYBR Green I Real-Time PCR method were compared for their efficiency for rapid accurate identification of E.coli and IB virus. A comparative analysis of these three assays was then performed, and the results indicated that the SYBR Green I Real-Time PCR had the highest sensitivity and specificity, with an advantage of fast turnaround over the other two assays, which is a valuable feature for identification and identification of E.coli and IB live vaccines.

\section{Materials and methods}

\subsection{Conventional culture method for} identification of E.coli on plate media:

Fourteen, serial 10-fold dilutions of E.coli commercial live attenuated vaccine were prepared in Tryptic soy broth then plated onto MacConkey (Mc) agar then incubated 
overnight at $37^{\circ} \mathrm{C}$. To rule out false positives, one uninoculated aliquot was used as a negative control in every experiment the method was applied following the standard procedures of the World Organization for Animal Health (OIE 2018) to determine the lower identification limit of the Conventional culture method.

\subsection{SPF Egg inoculation for identification of} $I B$ virus in SPF eggs:

Different serial ten dilutions of the commercial live attenuated IB vaccine was prepared to be inoculated in 9-11day old specific pathogenfree embryonated chicken eggs (5 eggs for each dilution), following the standard procedures of the World Organization for Animal Health (OIE 2018) to show lesion of IB virus on egg embryo as it show curling and dwarfing. The allantoic fluid was harvested and stored at $-70^{\circ} \mathrm{C}$ until used for RNA extraction.

\subsection{DNA extraction form E.coli:}

DNA extraction from diluted E.coli vaccine samples was performed using the QIAamp DNA Mini kit (Qiagen, Germany, GmbH) with modifications from the manufacturer's recommendations. Briefly, $200 \mu \mathrm{l}$ of the sample suspension was incubated with $10 \mu \mathrm{l}$ of proteinase $\mathrm{K}$ and $200 \mu \mathrm{l}$ of lysis buffer at $56^{\circ} \mathrm{C}$ for $10 \mathrm{~min}$. After incubation, $200 \mu \mathrm{l}$ of $100 \%$ ethanol was added to the lysate. The sample was then washed and centrifuged following the manufacturer's recommendations. Nucleic acid was eluted with $100 \mu 1$ of elution buffer provided in the kit.

\section{Oligonucleotide Primer:}

Primers used were supplied from Metabion (Germany) are listed in table (1).

PCR amplification for identification of E. coli: Primers were utilized in a $25-\mu 1$ reaction containing $24 \mu \mathrm{l}$ of EmeraldAmp Max PCR
Master Mix (Takara, Japan), $1 \mu$ l of each primer of 20 pmol concentration, $4.5 \mu \mathrm{l}$ of water, and $6 \mu 1$ of DNA template. The reaction was performed in a Biometra thermal cycler. A primary denaturation step was done at $95{ }^{\circ} \mathrm{C}$ for $5 \mathrm{~min}$, followed by 35 cycles of $94^{\circ} \mathrm{C}$ for $30 \mathrm{sec}$., $55^{\circ} \mathrm{C}$ for $40 \mathrm{sec}$. and $72^{\circ} \mathrm{C}$ for $45 \mathrm{sec}$. min. A final extension step was done at $72^{\circ} \mathrm{C}$ for $10 \mathrm{~min}$.

RNA extraction for IB virus:

RNA extraction from samples was performed using the QIAamp viral RNA Mini kit (Qiagen, Germany, GmbH). Briefly, $140 \mu 1$ of the sample suspension was incubated with 560 $\mu \mathrm{l}$ of AVL lysis buffer and $5.6 \mu \mathrm{l}$ of carrier RNA at room temperature for $10 \mathrm{~min}$. After incubation, $560 \mu \mathrm{l}$ of $100 \%$ ethanol was added to the lysate. The sample was then washed and centrifuged following the manufacturer's recommendations. Nucleic acid was eluted with $60 \mu 1$ of elution buffer provided in the kit.

\section{PCR amplification for detection of IB:}

Primers (table 2) were utilized in a 25- $\mu 1$ reaction containing $12.5 \mu \mathrm{l}$ of Quantitect probe Reverse transcriptase PCR buffer (QIAgen, Gmbh), $1 \mu \mathrm{l}$ of each primer of $20 \mathrm{pmol}$ concentration, $0.25 \mu 1$ of Reverse transcriptase enzyme $4.25 \mu 1$ of water, and $6 \mu 1$ of template. The reaction was performed in a Biometra thermal cycler. Reverse transcription was applied at $50{ }^{\circ} \mathrm{C}$ for $30 \mathrm{~min}$, a primary denaturation step was done at $95^{\circ} \mathrm{C}$ for $5 \mathrm{~min}$, followed by 35 cycles of $94^{\circ} \mathrm{C}$ for $30 \mathrm{sec}$., $48^{\mathrm{O}} \mathrm{C}$ for $40 \mathrm{sec}$. and $72^{\mathrm{O}} \mathrm{C}$ for $45 \mathrm{sec}$. min. A final extension step was done at $72^{\circ} \mathrm{C}$ for 10 $\min$.

\section{Analysis of the PCR Products:}

The products of PCR were separated by electrophoresis on $1.5 \%$ agarose gel (Applichem, Germany, GmbH) in $1 \mathrm{x}$ TBE buffer at room temperature using gradients of $5 \mathrm{~V} / \mathrm{cm}$. For gel analysis, $15 \mu \mathrm{l}$ of the products 
were loaded in each gel slot. Gelpilot $100 \mathrm{bp}$ (Qiagen, Germany, GmbH) and a generuler 100 bp ladder (Fermentas, Germany) were used to determine the fragment sizes. The gel was photographed by a gel documentation system (Alpha Innotech, Biometra) and the data was analyzed through computer software.

\section{E. coli SYBR I green real time PCR:}

Primers (table 3 ) were utilized in a $25-\mu 1$ reaction containing $12.5 \mu \mathrm{l}$ of the $2 \mathrm{x}$ QuantiTect SYBR Green PCR Master Mix (Qiagen, Germany, GmbH), $0.5 \mu \mathrm{l}$ of each primer of $20 \mathrm{pmol}$ concentration, $8.5 \mu \mathrm{l}$ of water, and $3 \mu \mathrm{l}$ of RNA template. The reaction was performed in a Stratagene MX3005P real time PCR machine.

\section{IB SYBR green rt-PCR:}

Primers (table 3) were utilized in a $25-\mu 1$ reaction containing $12.5 \mu \mathrm{l}$ of the $2 \mathrm{x}$ QuantiTect SYBR Green PCR Master Mix (Qiagen, Germany, $\mathrm{GmbH}$ ), $0.25 \mu \mathrm{l}$ of RevertAid Reverse Transcriptase $(200 \mathrm{U} / \mu \mathrm{L})$ (Thermo Fisher), $0.5 \mu 1$ of each primer of 20 pmol concentration, $8.25 \mu 1$ of water, and $3 \mu 1$ of RNA template. The reaction was performed in a Stratagene MX3005P real time PCR machine.

\section{RESULTS}

The analytical sensitivity of these three assays was assessed through serial dilutions of each vaccine

Determination of the least detectable concentration of live attenuated E.coli live vaccine in culture media:

Among the diluted vaccine samples eleven dilutions revealed positive E.coli colonies on Mac agar media.

Determination of the least detectable concentration of live attenuated IB live vaccine in SPF eggs:
Among the diluted vaccine samples seven dilutions revealed positive IB picture of embryos curling and dwarfing.

Conventional PCR:

For identification of E.coli and IB and discrimination of the lower detectable concentration than the conventional identification method in live attenuated E.coli live vaccines. The $720 \mathrm{bp}$ and $570 \mathrm{bp}$ amplicons specific to E.coli and IB, respectively, were detected by routine PCR with the specific primers (Table 1). The identification limit was showed in fig 1 and 2 .

Identification of E.coli:

The results of PCR for the amplification of the different dilutions of E.coli live attenuated vaccine were positive at an amplification of $720 \mathrm{bp}$ specific for the Genus E.coli for the dilutions from the $12^{\text {th }}$ to $27^{\text {th }}$ but the $28^{\text {th }}, 29^{\text {th }}$ and $30^{\text {th }}$ were negative.

\section{Identification of IB:}

PCR targeted a sequence corresponding to the IB virus. The obtained PCR products of $570 \mathrm{bp}$ in length were separated on a $1.5 \%$ agarose gel stained with ethidium bromide (Fig. 2). The results of PCR for the amplification of the different dilutions of IB live attenuated vaccine were detectable at an amplification of $570 \mathrm{bp}$ specific for the dilutions from the 8th to 30th but the dilutions from 31th to 35th were negative.

Specificity of SYBR green I real-time RT-PCR:

For identification of E.coli and IB and discrimination of the lower detectable concentration than the conventional PCR assay in live attenuated E.coli and IB vaccines.

\section{Identification of E.coli:}

The amplification curve showed that $28^{\text {th }}$ and $29^{\text {th }}$ dilutions were considered as positive and dilution $30^{\text {th }}$ was considered as negative (fig $3 \mathrm{~A})$. 
Melting peaks analysis on the PCR products E.coli vaccine strains and tenfold serially diluted DNA did not indicate primer dimers or nonspecific products. Specific amplification of the E.coli target sequence was identified by the generation of a melt peak. The specificity of the SYBR green-I real-time RT-PCR was 100 $\%$ since detectable fluorescent signals was not observed with the negative control. Only the E.coli vaccine strain genetic material was detected (Fig. 3B).

\section{Identification of IB:}

The amplification curve showed that $31^{\text {th }}$ dilution was considered as positive but dilution $33^{\text {th }}$ and 35 was considered as negative (fig 4A).
Melting peaks analysis on the PCR products IB vaccine strains and tenfold serially diluted cDNA did not indicate primer dimers or nonspecific products. Specific amplification of the IB target sequence was identified by the generation of a melt peak. The specificity of the SYBR green-I real-time RT-PCR was 100 $\%$ since detectable fluorescent signals was not observed with the negative control. Only the IB vaccine strain genetic material was detected (Fig. 4B).

Table 1: E. coli Primers sequences, target gene, amplicon sizes.

\begin{tabular}{llll}
\hline $\begin{array}{l}\text { Target } \\
\text { gene }\end{array}$ & Primers sequences & $\begin{array}{l}\text { Amplified } \\
\text { segment (bp) }\end{array}$ & Reference \\
\cline { 1 - 2 } phoA & CGATTCTGGAAATGGCAAAAG & 720 & Hu et al., \\
\cline { 2 - 3 } & \multicolumn{2}{c}{ CGTGATCAGCGGTGACTATGAC } & 2011 \\
\hline
\end{tabular}

Table 2: IB Primers sequences, target gene, amplicon sizes.

\begin{tabular}{lllll}
\hline $\begin{array}{l}\text { Target } \\
\text { gene }\end{array}$ & Primers sequences & $\begin{array}{l}\text { Amplified } \\
\text { segment }(\mathrm{bp})\end{array}$ & Reference \\
\cline { 1 - 2 } & & $570 \mathrm{bp}$ & Abdel-Moneim & et \\
\cline { 1 - 2 } & ACT ACT ACCAAAGTG CCT & & al., 2002 & \\
\cline { 2 - 3 } & $\begin{array}{l}\text { ACA TCT TGT GCA GTA CCA } \\
\text { TTA ACA }\end{array}$ & & & \\
& & & &
\end{tabular}


Mahmoud et al. (2018). BVMJ-35(2): 57-66

Table 3: IB Primers sequences, target gene, amplicon sizes.

\begin{tabular}{|c|c|c|c|c|c|c|c|c|c|c|}
\hline \multirow[b]{2}{*}{$\begin{array}{l}\text { Tar } \\
\text { get }\end{array}$} & \multirow[b]{2}{*}{ Primers sequences } & \multirow[b]{2}{*}{$\begin{array}{l}\text { Revers } \\
\text { e } \\
\text { transcri } \\
\text { ption }\end{array}$} & \multirow[b]{2}{*}{$\begin{array}{l}\text { Primar } \\
\text { y } \\
\text { denatur } \\
\text { ation }\end{array}$} & \multicolumn{3}{|c|}{ Amplification ( 40 cycles) } & \multicolumn{3}{|c|}{$\begin{array}{l}\text { Dissociation curve }(1 \\
\text { cycle) }\end{array}$} & \multirow[b]{2}{*}{$\begin{array}{l}\text { Refer } \\
\text { ence }\end{array}$} \\
\hline & & & & $\begin{array}{l}\text { Second } \\
\text { ary } \\
\text { denatur } \\
\text { ation }\end{array}$ & $\begin{array}{l}\begin{array}{l}\text { Anne } \\
\text { aling }\end{array} \\
\text { (Optic } \\
\text { s on) }\end{array}$ & $\begin{array}{l}\text { Exten } \\
\text { sion }\end{array}$ & $\begin{array}{l}\text { Second } \\
\text { ary } \\
\text { denatur } \\
\text { ation }\end{array}$ & $\begin{array}{l}\text { Anne } \\
\text { aling }\end{array}$ & $\begin{array}{l}\text { Final } \\
\text { denatur } \\
\text { ation }\end{array}$ & \\
\hline \multirow[b]{2}{*}{$\begin{array}{l}\text { E. } \\
\text { coli }\end{array}$} & $\begin{array}{l}\text { CGATTCTGGAAAT } \\
\text { GGCAAAAG }\end{array}$ & & \multirow{4}{*}{$\begin{array}{l}94^{\circ} \mathrm{C} \\
15 \mathrm{~min} .\end{array}$} & \multirow{4}{*}{$\begin{array}{l}94^{\circ} \mathrm{C} \\
15 \mathrm{sec} .\end{array}$} & \multirow{2}{*}{$\begin{array}{l}55^{\circ} \mathrm{C} \\
30 \\
\text { sec. }\end{array}$} & \multirow{4}{*}{$\begin{array}{l}72^{\circ} \mathrm{C} \\
30 \\
\text { sec. }\end{array}$} & \multirow{4}{*}{$\begin{array}{l}94^{\circ} \mathrm{C} \\
1 \mathrm{~min} .\end{array}$} & $55^{\circ} \mathrm{C}$ & \multirow{4}{*}{$\begin{array}{l}94^{\circ} \mathrm{C} \\
1 \mathrm{~min} .\end{array}$} & \\
\hline & $\begin{array}{l}\text { CGTGATCAGCGGT } \\
\text { GACTATGAC }\end{array}$ & $30 \mathrm{~min}$. & & & & & & $1 \mathrm{~min}$. & & $\begin{array}{l}\text { Hu et } \\
\text { al., } \\
2011\end{array}$ \\
\hline \multirow[b]{2}{*}{ IB } & $\begin{array}{l}\text { ACT ACT ACC AAA } \\
\text { GTG CCT }\end{array}$ & & & & $48^{\circ} \mathrm{C}$ & & & $48^{\circ} \mathrm{C}$ & & Abdel \\
\hline & $\begin{array}{l}\text { ACA TCT TGT GCA } \\
\text { GTA CCA TTA ACA }\end{array}$ & - & & & $\begin{array}{l}30 \\
\text { sec. }\end{array}$ & & & $1 \mathrm{~min}$. & & $\begin{array}{l}\text { Mone } \\
\text { im et } \\
\text { al., } \\
2002\end{array}$ \\
\hline
\end{tabular}

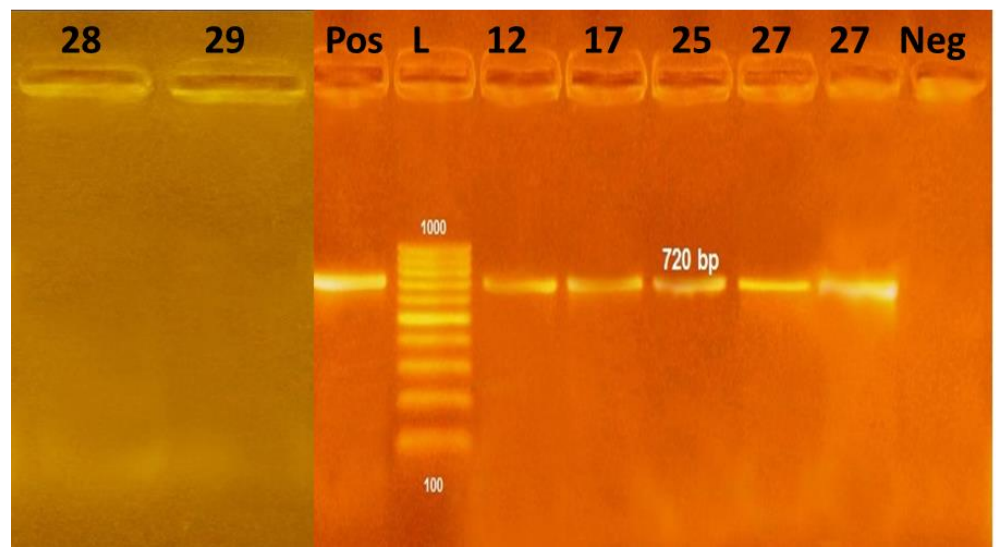

Fig.1. The sensitivity of conventional PCR assay for identification of E.coli.

Lane L. 100bp marker.

Lanes 12-27. Positive amplification of 720bp fragment of E.Coli.

Lane pos. positive control E.Coli (ATCC 43 482).

Lane neg. negative control.

Lanes 28 and 29. Negative amplification of 720bp fragment of E.Coli of $28^{\text {th }}$ and $29^{\text {th }}$ dilutions. 


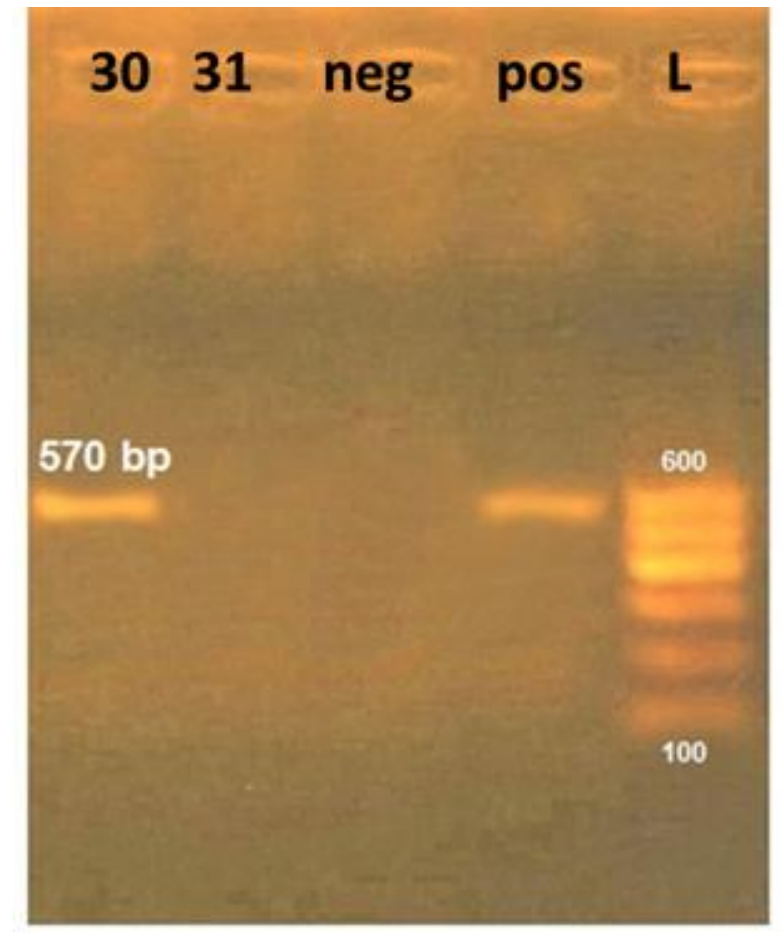

Fig.2. The sensitivity of conventional PCR assay for identification of E.coIB.

Lane L. 100bp marker.

Lane pos. positive control IB (Access. No. AF395531).

Lane neg. negative control.

Lanes 31. Negative amplification of 570bp fragment of IB of $31^{\text {th }}$ dilution.

Lanes 30. Positive amplification of 570bp fragment of IB.
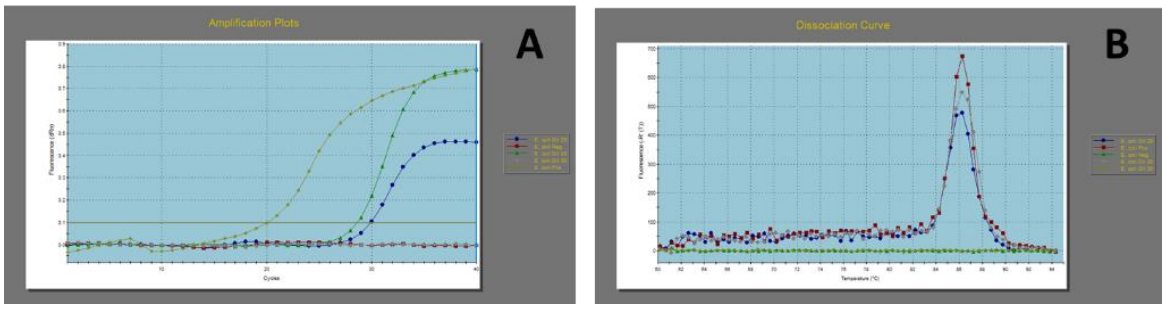

Fig.3. (A) SYBR Green Real-Time PCR the specific fluorescent signals of E.Coli. (B) The dissociation curve analysis of SYBR Green real-time PCR product of E.Coli.
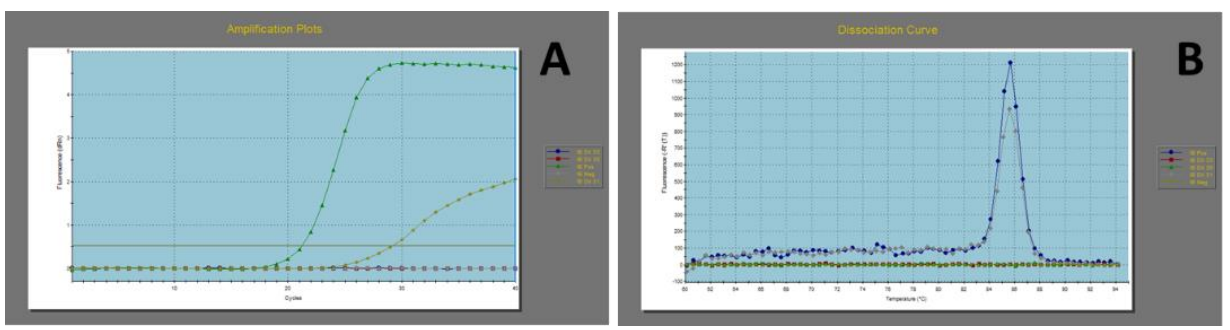

Fig.4. (A) SYBR Green Real-Time PCR the specific fluorescent signals of IB. (B) the dissociation curve analysis of SYBR Green real-time PCR product of IB. 


\section{DISCUSSION}

Virus isolation was a gold standard method for viral identification, but it is a timeconsuming, labor-intensive work and has limitations. Up to the present time, there are several methods based on the conventional PCR and SYBR Green Real-Time PCR to detect and identify IB (Zhou et al., 2017). The use of PCR for diagnosis of viral diseases has increased to the point that the assay is now considered the gold standard instead of viral isolation. SYBR Green Real-Time PCR has catalyzed wider acceptance of PCR as a diagnostic tool because it is more rapid, sensitive, and reproducible, and the risk of carryover contamination is minimized compared to conventional PCR (Siham et al., 2016).

To be an alternative method, in this study, three assays for detecting the E.coli and IB in the live attenuated vaccines have been established and evaluated The SYBR Green Real-Time PCR is the most convenient method for the identification of E.coli and IB as it is highly sensitive(Zhou et al., 2017).

The results of using conventional identification of IB by SPF inoculation technique can detect IB until the $7^{\text {th }}$ dilution while the conventional culture method could detect E.coli until the $11^{\text {th }}$ dilution. The PCR assay could detect the virus RNA until the $30^{\text {th }}$ dilution and the bacterial DNA until the $27^{\text {th }}$ dilution but this method needs amplification product separations by gel electrophoresis these are a time-consuming protocols. These results agree with (Ana et al., 2013) as he mentioned that Virus isolation (VI) is considered as the gold standard, but this method is time-consuming because several passages may be required to detect the virus. To overcome this drawback, different molecular assays have been developed.
On the other hand SYBR Green I-based real-time PCR assays have proven to be one of the most effective tools in the rapid and sensitive identification of a variety of viral pathogens (Ana et al., 2013) as it was able to detect the virus until the $31^{\text {th }}$.

The SYBR Green I-based real-time PCR assay can detect very low numbers of bacterial cells or viral particles in vaccine samples even with high levels of background flora and common PCR inhibitors (Hyang-Mi et al., 2005).

The assay developed in the current study displayed an analytical sensitivity higher than the VI test or the conventional PCR assays. This last finding could be for a number of different reasons. First, SYBR Green I-based real-time based on the principle of identification of the fluorescent signal emitted by specific amplification products, has provided the assay with a higher sensitivity as compared with end point-conventional PCR. Second, viral isolation can be affected by the neutralising action of the antibodies (Ana et al., 2013).

On the one hand, the SYBR Green I is less influenced by different genetic backgrounds. . Thus, the use of SYBR Green I is considered as a broad-spectrum identification format. On the other hand, when using SYBR Green $I$ as the format of identification, different amplicons can be distinguished by melting curve analysis. The melting curve for a specific PCR product is determined by the reduction in relative fluorescence when the double-strand of DNA is denatured by the temperature action. Therefore, the peak location on a melting curve (Tm) depends on the sequence, GC/AT ratio and the length of the resulting amplicon. The RT-PCR assay based on SYBR Green-I identification coupled with melting curves analysis for the identification of IB virus is 
proposed. The results indicate the usefulness of this tool for rapid identification of IB (Ana et al., 2013). It is also considered simpler and cheaper than other fluorescent dyes (Hairul et al., 2008).

To date, the approaches to detect E.coli and IB include conventional culture method; virus isolation and conventional PCR are timeconsuming with relatively low specificity and sensitivity. Improved diagnostic assays with a broad identification spectrum for the identification of E.coli and IB are indeed needed.

\section{Conclusion}

The SYBR Green I-based real-time RTPCR assay provides a powerful tool for the identification of E.coli and IB. The proposed method seems to be effective, rapid and reproducible, showed that neither falsepositive nor false-negative results were obtained. The specificity of the reaction was confirmed by the determination of the Tm, specific for the amplicon obtained, that allows to eliminate the phase of electrophoresis, which is time-consuming and requires the use of ethidium bromide, a potent mutagenic agent, that is not suitable for routine use.

\section{REFERENCES}

Abdel-Moneim, A.S.; Madbouly, H.M.; Gelb, J.Jr. and Landman, S. (2002): Isolation and identification of Egypt/BeniSuef/01 a novel infectious bronchitisvirus genotype. Vet. Med. J. Giza, 50(4): 1065-1078.

Ana M. Acevedo, Carmen L. Perera, Armando Vega, Liliam Ríos, Liani Coronado, Damarys Relova, Maria T. Frías, Llilianne Ganges, José I. Núñez, Lester J. Pérez (2013): A duplex SYBR Green I-based real-time RT-PCR assay for the simultaneous detection and differentiation of Massachusetts and non-Massachusetts serotypes of infectious bronchitis virus. Molecular and Cellular Probes 27; 184-192.

Cavanagh D. (2007): Coronavirus avian infectious bronchitis virus. Vet Res;38: 281e-97.

Hairul H. Aini, Omar A.R., Hair-Bejo M., Aini I. (2008): Comparison of Sybr Green I, ELISA and conventional agarose gel-based PCR in the detection of infectious bursal disease virus. Microbiological Research 163; 556563

Hoorfar J., P. Ahrens, P. R_dstrom (2000): Automated 5' nuclease PCR assay for identification of Salmonella enterica. J. Clin. Microbiol. 38, 3429-35.

Hu, Q.; Tu, J.; Han, X.; Zhu, Y.; Ding, C. and Yu, S. (2011): Development of multiplex PCR assay for rapid detection of Riemerella anatipestifer, Escherichia coli, and Salmonella enterica simultaneously from ducks. Journal of Microbiological Methods 87 (2011) 6469.

Hyang-Mi Nam, Velusamy Srinivasan, Barbara E. Gillespie, Shelton E. Murinda, Stephen P. Oliver (2005): Application of SYBR green real-time PCR assay for specific detection of Salmonella spp. in dairy farm environmental samples. Journal of Food Microbiology 102; 161- 171.

$$
\begin{aligned}
& \text { ICTV virus taxonomy (2009): } \\
& <\text { http://ictvonlineorg/virusTaxonomy } \\
& \text { aspversion/2009>. }
\end{aligned}
$$

Jothikumar, N., Griffiths, M.W (2002): Rapid detection of Escherichia coli O157:H7 with multiplex real-time PCR assays. Appl. Environ. Microbiol. 68, 3169- 
3171.

OIE (office international des epizooties) (2018): Terrestrial animal health code [chapter 2.3.2 avian infectious bronchitis]. OIE (World Organisation for Animal Health. http://www.oie.int/eng/normes/mcode/ en_chapitre_1.10.4.pdf.

Schalk AF, Hawn MC (1931): An apparently new respiratory disease of chicks. J Am Vet Med Assoc; 78:413e-22.

Siham Fellahi, Mehdi El Harrak, Jens H. Kuhn, Ghizlane Sebbar, El Arbi Bouaiti, Khadija Khataby, Ouafae Fassi Fihri1, Mohammed El Houadfi and My Mustapha Ennaji(2016):Comparison of SYBR green I real-time RT-PCR with conventional agarose gel-based RT PCR for the diagnosis of infectious bronchitis virus infection in chickens in Morocco. BMC Res Notes 9:231.

Zhou X, Zhang T, Song D, Huang T, Peng Q, Chen Y, Li A, Zhang F, Wu Q, Ye Y, Tang Y, 2017 Comparison and evaluation of conventional RT-PCR, SYBR green I and TaqMan real-time RT-PCR assays for the detection of porcine epidemic diarrhea virus (2017): 33: 36-41. doi: 10.1016/j.mcp.2017.02.002. Epub 2017 Feb 7. 